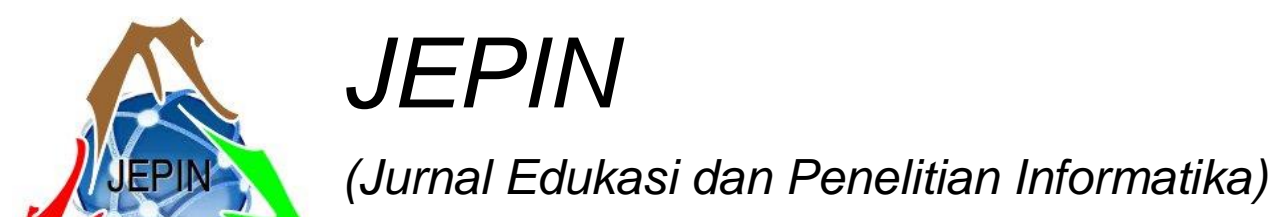

Vol. 6

No. 2

\title{
Tinjauan Kasus Model Speech Recognition: Hidden Markov Model
}

\author{
Deny Jollyta $^{\# 1}$, Dwi Oktarina ${ }^{\# 2}$, Johan ${ }^{\# 3}$ \\ \#Program Studi Teknik Informatika, Sekolah Tinggi Ilmu Komputer Pelita Indonesia \\ Jalan Jendral Ahmad Yani No. 78-88 Pekanbaru \\ ${ }^{1}$ deny.jollyta@lecturer.pelitaindonesia.ac.id \\ ${ }^{2}$ dwi.oktarina@lecturer.pelitaindonesia.ac.id \\ ${ }^{3}$ johan@lecturer.pelitaindonesia.ac.id
}

\begin{abstract}
Abstrak - Teknologi pengenal suara (speech recognition) merupakan teknologi yang berkembang pesat dalam bidang kecerdasan buatan (artificial intelligent). Saat ini, teknologi pengenal suara menjadi hal yang komersil melalui berbagai media teknologi seperti smartphone dan komputer. Salah satu pembentuk struktur pengenal suara agar dapat bekerja pada perangkat tersebut adalah model statistik pengenal suara Hidden Markov Model (HMM). Penerapan HMM pada berbagai kasus menunjukkan bahwa model ini cocok dengan berbagai macam data. Tulisan ini merupakan sebuah tinjauan untuk model HMM yang bertujuan untuk memberikan gambaran dan pemahaman terhadap kinerja HMM melalui rangkuman sejumlah penelitian yang digunakan dalam berbagai data. Penerapan HMM tersebut menunjukkan optimalisasi kinerja HMM dan tinjauan terhadap sejumlah penelitian menunjukkan bahwa tingkat keberhasilan HMM dalam mengenali data mencapai $\mathbf{7 1 . 4 3 \%}$.
\end{abstract}

Kata kunci-Speech recognition, artificial intelligent, model statistik, hidden markov model, media teknologi

\section{Pendahuluan}

Automatic Speech Recognition (ASR) dibangun dari bemacam-macam model statistik yakni model Akustik, model Bahasa, model Leksikon dan model Hidden Markov. Model Hidden Markov atau dikenal dengan Hidden Markov Model (HMM) adalah model yang umum digunakan untuk menyelesaikan berbagai kesulitan dalam pengenalan suara [1]. Keluaran HMM adalah sekuens dari simbol atau kuantitas, dimana sebuah sinyal dari pengucapan bisa dilihat seperti piecewise stationary signal atau short-time stationary signal [2]. HMM dikenal dapat diujikan secara otomatis, sederhana dan secara komputasi layak untuk digunakan[3],[4].

Tinjauan tentang kinerja HMM menjadi tujuan tulisan ini dijabarkan. Sejumlah alasan HMM digunakan, tergambar pada berbagai penelitian yang telah dilakukan hingga sekarang. Pada penelitian [5], HMM membantu mengenali emosi manusia melalui suara. Percakapan yang diubah menjadi teks dan sebaliknya, merupakan hasil penggunaan HMM dengan program dinamik [6] dan kombinasi HMM dengan beberapa sinyal audio [7]. HMM juga sangat membantu dalam pengenalan suara di bidang akademik dan industri sejak tahun 2012 [8], [9], [10] serta mengenali wajah [11].

Pada beberapa penelitian yang membutuhkan database suara dengan jumlah besar, HMM sering dikombinasikan atau digabungkan dengan model atau algoritma berbeda untuk memperoleh hasil suara yang lebih jelas dan dipahami. Penelitian [12] memperlihatkan bagaimana HMM dikembangkan yang disebut dengan utterance. Utterance adalah pengucapan satu kata, beberapa kata, kalimat bahkan beberapa kalimat. Artinya, kemungkinan HMM dapat bekerja lebih baik bila digabungkan dengan metode atau model atau algoritma lainnya.

Selain itu, HMM juga dapat mendeteksi berbagai kegiatan dalam dunia bisnis, seperti fraud [13], perkiraan harga minyak mentah [14], dan prediksi peluang kenaikan harga saham [15]. Tidak hanya itu, HMM turut membantu menghasilkan penelitian yang mampu mendeteksi noise saat HMM beroperasi [16] dan mengubah nilai threshold seperti teta [17].

\section{MATERI DAN MEtode PENELITIAN}

\section{A. Unsur dan Arsitektur HMM}

HMM merupakan pengembangan dari teorema Bayes dan proses Markov [18]. HMM bertujuan untuk menentukan atau merepresentasikan parameter (state) tersembunyi berdasarkan sejumlah data observasi yang ada. Penerapan ASR melalui model HMM menjadi dasar berkembangnya HMM pada berbagai kasus pengenalan suara. Secara umum, model HMM memiliki unsur-unsur sebagai berikut [19]:

1) $N$ : yaitu jumlah state dalam model. Secara umum state saling terhubung satu dengan yang lain, dan suatu state bisa mencapai semua state yang lain dan sebaliknya (disebut model ergodic). Namun hal tersebut tidak mutlak, terdapat kondisi lain dimana suatu state hanya bisa berputar ke diri sendiri dan berpindah ke satu state berikutnya, hal ini bergantung pada implementasi dari model. 
2) $M$ : yaitu jumlah observasi simbol secara unik pada tiap state, misalnya: karakter dalam alfabet, dimana state adalah huruf dalam kata.

3) State Transition Probability: yaitu kemungkinan perubahan kata dengan ketentuan $\mathrm{A}=\left\{a_{i j}\right\}$

4) Observation Symbol Probability pada State: yaitu kegiatan observasi pada kemungkinan perubahan setiap state $\mathrm{j}, \mathrm{B}=\left\{b_{j}(k)\right\}$

5) Initial State Distribution: yaitu inisialisasi state yang telah didistribusikan $\pi=\left\{\pi_{i}\right\}$

Dengan memberikan nilai pada N, M, A, B, dan $\pi$, HMM dapat digunakan sebagai generator untuk menghasilkan urutan observasi.

HMM sangat berpotensi untuk dikembangkan sesuai dengan kasus pengenalan suara yang hendak dibangun [12]. Hal ini dikarenakan HMM memiliki framework yang dibagun dari unsur matematis, mudah diterapkan dan layak secara komputasi [20].

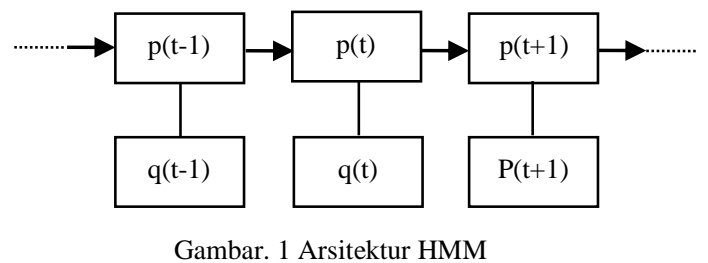

Gambar 1 menunjukkan bahwa arsitektur umum HMM yang terdiri dari arbitrary variable yang mampu menerima sejumlah nilai. Artinya, HMM merupakan model yang mudah dimodifikasi.

Semua kasus ASR yang menggunakan HMM membentuk suatu diagram kerja yang menggambarkan sistematika HMM. Gambar 2 merupakan arsitektur HMM berdasarkan pengenal suara yang umum digunakan [21].

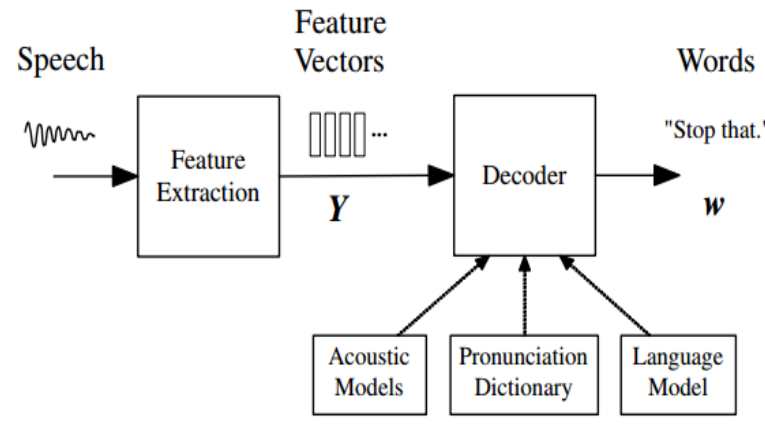

Gambar. 2 Arsitektur HMM berdasarkan prinsip pengenal suara

Berdasarkan Gambar 2, unsur HMM terletak pada blok feature extraction dimana setiap kata atau ucapan yang ditangkap, dikenali terlebih dulu sebelum diubah ke teks yang dikenali.

\section{B. Konsep Kerangka Pemikiran}

Tulisan dalam bentuk tinjauan kasus ini disusun menggunakan metode penelitian Systematic Mapping
Study karena metode ini sesuai dengan penelitian yang berbasis tinjauan kasus. Adapun konsep yang dibangun untuk memperoleh kesimpulan yang diinginkan, terdapat pada Gambar 3.

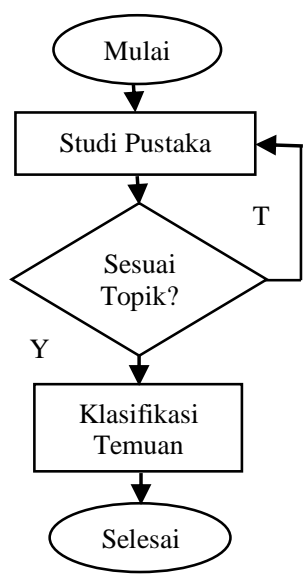

Gambar. 3 Konsep kerangka pemikiran

Langkah awal studi dilakukan melalui pemilihan referensi yang bersesuaian dengan topik pembahasan yakni ASR dan HMM. Ruang lingkup yang dibahas adalah berbagai macam kasus yang menggunakan HMM, termasuk pengembangannya. Referensi terpilih dikaji dan disimpulkan. Hasilnya berupa klasifikasi dari temuan sesuai topik. Diharapkan hasil tersebut menjadi informasi yang bermanfaat bagi pengguna dalam memahami kinerja, khususnya HMM.

\section{HASIL DAN ANALISIS}

HMM telah diterapkan pada bermacam- macam kasus. Tidak sedikit pula pengembangan dan modifikasi terhadap HMM dilakukan. Data uji umumnya diambil dari database yang disiapkan peneliti karena umumnya speech recognizer mempunyai kemampuan terbatas untuk mengenali kata yang diujikan. Berikut dijabarkan berbagai hasil penelitian yang menerapkan HMM dalam konsep ASR yang terangkum dalam Tabel 1 dan 2 .

TABEL I

HASIL PENELITIAN DAN ANALISIS BAGIAN 1

\begin{tabular}{|c|c|c|c|}
\hline $\begin{array}{c}\text { Peneliti } \\
\text { (a) }\end{array}$ & $\begin{array}{c}\text { Judul } \\
\text { (b) }\end{array}$ & $\begin{array}{c}\text { Model } \\
\text { (c) }\end{array}$ & $\begin{array}{c}\text { Properti } \\
\text { (d) }\end{array}$ \\
\hline $\begin{array}{l}{[2]} \\
\text { A. S. } \\
\text { Sunny }\end{array}$ & $\begin{array}{l}\text { Speech } \\
\text { Recognition } \\
\text { Menggunakan } \\
\text { Algoritma } \\
\text { Program } \\
\text { Dinamis }\end{array}$ & $\begin{array}{l}\text { HMM- } \\
\text { Dynamic } \\
\text { Time } \\
\text { Warping } \\
\text { (HMM- } \\
\text { DTW) }\end{array}$ & $\begin{array}{l}\text { Vocal Signal } \\
\text { Analysis, } \\
\text { teorema } \\
\text { Faourier, } \\
\text { Algoritma } \\
\text { Dynamic Time } \\
\text { Warping }\end{array}$ \\
\hline $\begin{array}{l}{[3]} \\
\text { C. P. } \\
\text { Dalmiya, } \\
\text { V. S. } \\
\text { Dharun, } \\
\text { and K. P. } \\
\text { Rajesh }\end{array}$ & $\begin{array}{l}\text { An Efficient } \\
\text { Method for } \\
\text { Tamil Speech } \\
\text { Recognition } \\
\text { using MFCC } \\
\text { and DTW for } \\
\text { Mobile } \\
\text { Applications }\end{array}$ & $\begin{array}{l}\text { MelFrequenc } \\
\text { y Cepstral } \\
\text { Coefficients } \\
\text { (MFCC)- } \\
\text { DTW, Linier } \\
\text { Predictive } \\
\text { Coding- } \\
\text { HMM (LPC- }\end{array}$ & $\begin{array}{l}\text { Mel frequency } \\
\text { Cepstral } \\
\text { Coefficients, } \\
\text { algoritma } \\
\text { HMM }\end{array}$ \\
\hline
\end{tabular}




\begin{tabular}{|c|c|c|c|c|c|c|c|}
\hline $\begin{array}{l}\text { Peneliti } \\
\text { (a) }\end{array}$ & $\begin{array}{l}\text { Judul } \\
\text { (b) }\end{array}$ & $\begin{array}{c}\text { HMM) } \\
\begin{array}{c}\text { Model } \\
\text { (c) }\end{array}\end{array}$ & $\begin{array}{l}\text { Properti } \\
\text { (d) }\end{array}$ & & $\begin{array}{l}\text { Technology } \\
\text { Stock } \\
\text { Prediction } \\
\end{array}$ & \multirow[b]{2}{*}{$\begin{array}{l}\text { Model } \\
\text { (c) }\end{array}$} & \multirow[b]{2}{*}{$\begin{array}{l}\text { Properti } \\
\text { (d) }\end{array}$} \\
\hline $\begin{array}{l}{[4]} \\
\text { G. }\end{array}$ & $\begin{array}{l}\text { Automatic } \\
\text { Speech }\end{array}$ & HMM & $\begin{array}{l}\text { Mel-frequency } \\
\text { cepstral }\end{array}$ & \multirow{3}{*}{$\begin{array}{l}\begin{array}{l}\text { Peneliti } \\
\text { (a) }\end{array} \\
\text { [25] } \\
\text { J. Lemos, } \\
\text { S. Patil, } \\
\text { S. Save, } \\
\text { and H. } \\
\text { Pise }\end{array}$} & $\begin{array}{c}\text { Judul } \\
\text { (b) }\end{array}$ & & \\
\hline $\begin{array}{l}\text { Muhamm } \\
\text { ad, Y. A. } \\
\text { Alotaibi, } \\
\text { and M. } \\
\text { N. Huda }\end{array}$ & $\begin{array}{l}\text { Recognition } \\
\text { for Bangla } \\
\text { Digits }\end{array}$ & & $\begin{array}{l}\text { coefficients, } \\
\text { HMM toolkit }\end{array}$ & & $\begin{array}{l}\text { Credit Card } \\
\text { Fraud } \\
\text { Detection } \\
\text { Using Hidden } \\
\text { Markov }\end{array}$ & $\begin{array}{l}\text { HMM, Nä̈ve } \\
\text { Bayes }\end{array}$ & $\begin{array}{l}\text { Jumlah } \\
\text { transaksi, } \\
\text { pengukuran } \\
\text { statistik } \\
\text { akurasi, rata- }\end{array}$ \\
\hline \multirow{2}{*}{$\begin{array}{l}{[6]} \\
\text { A. } \\
\text { Trivedi, } \\
\text { N. Pant, } \\
\text { P. Shah, } \\
\text { S. Sonik, } \\
\text { and S. } \\
\text { Agrawal }\end{array}$} & \multirow{2}{*}{$\begin{array}{l}\text { Speech to text } \\
\text { and text to } \\
\text { speech } \\
\text { recognition } \\
\text { systems-A } \\
\text { review }\end{array}$} & \multirow[t]{2}{*}{ HMM-DTW. } & \multirow{2}{*}{$\begin{array}{l}\text { Algoritma } \\
\text { DTW, Linear } \\
\text { Predictive } \\
\text { Coding, Mel- } \\
\text { Frequency } \\
\text { Cestrum Co- } \\
\text { efficient }\end{array}$} & & $\begin{array}{l}\text { Model and } \\
\text { Nä̈ve Bayes }\end{array}$ & & $\begin{array}{l}\text { rata dan } \\
\text { standar deviasi }\end{array}$ \\
\hline & & & & \multirow{2}{*}{$\begin{array}{l}{[26]} \\
\text { S. } \\
\text { Bhende, } \\
\text { K. } \\
\text { Thakur, } \\
\text { J. } \\
\text { Teseng, } \\
\text { M. L. } \\
\text { Ali, and } \\
\text { N. Wang }\end{array}$} & \multirow[t]{2}{*}{$\begin{array}{l}\text { Character } \\
\text { Recognition } \\
\text { Using Hidden } \\
\text { Markov } \\
\text { Models }\end{array}$} & \multirow[t]{2}{*}{ HMM } & \multirow[t]{2}{*}{$\begin{array}{l}\text { algoritms } \\
\text { Virtebi, Self } \\
\text { Organizing } \\
\text { Map }\end{array}$} \\
\hline \multirow{3}{*}{$\begin{array}{l}\text { [19] } \\
\text { J. M. T. } \\
\text { S., D. } \\
\text { Puspitani } \\
\text { ngrum, } \\
\text { and B. } \\
\text { Susilo }\end{array}$} & \multirow{3}{*}{$\begin{array}{l}\text { Penerapan } \\
\text { Speech } \\
\text { Recognition } \\
\text { Pada } \\
\text { Permainan } \\
\text { Teka-Teki } \\
\text { Silang } \\
\text { Menggunakan } \\
\text { Metode } \\
\text { Hidden } \\
\text { Markov } \\
\text { Model } \\
\text { (HMM) } \\
\text { Berbasis } \\
\text { Desktop } \\
\end{array}$} & \multirow[t]{3}{*}{ HMM } & \multirow{3}{*}{$\begin{array}{l}\text { Feature } \\
\text { extraction, } \\
\text { LPC, } \\
\text { pengukuran } \\
\text { statistik } \\
\text { maksimum } \\
\text { atau tertingi }\end{array}$} & & & & \\
\hline & & & & $\begin{array}{l}\text { [27] } \\
\text { R. } \\
\text { Alghamd } \\
\text { i }\end{array}$ & $\begin{array}{l}\text { Hidden } \\
\text { Markov } \\
\text { Models } \\
\text { (HMMs) and } \\
\text { Security } \\
\text { Applications }\end{array}$ & HMM & $\begin{array}{l}\text { Algoritma } \\
\text { Forward- } \\
\text { Backward, } \\
\text { algoritma } \\
\text { Viterbi, } \\
\text { accuracy } \\
\text { measurement }\end{array}$ \\
\hline & & & & \multirow{2}{*}{$\begin{array}{l}{[28]} \\
\text { D. } \\
\text { Abdullah } \\
\text { and R. } \\
\text { Ramadha } \\
\text { n }\end{array}$} & \multirow{2}{*}{$\begin{array}{l}\text { Implementasi } \\
\text { Algoritma } \\
\text { Hidden } \\
\text { Markov } \\
\text { Model } \\
\text { Sebagai } \\
\text { Pengenalan } \\
\text { Perintah } \\
\text { Suara Pada } \\
\text { Aplikasi } \\
\text { Winamp }\end{array}$} & \multirow{2}{*}{$\begin{array}{l}\text { HMM, } \\
\text { Linear } \\
\text { Predective } \\
\text { Coding } \\
\text { (LPC) }\end{array}$} & \multirow{2}{*}{$\begin{array}{l}\text { Sinyal suara } \\
\text { dari aplikasi } \\
\text { winamp, } \\
\text { instruksi } \\
\text { perintah yang } \\
\text { diuji }\end{array}$} \\
\hline \multirow{2}{*}{$\begin{array}{l}{[22]} \\
\text { M. A. } \\
\text { Menacer, } \\
\text { O. Mella, } \\
\text { D. Fohr, } \\
\text { D. } \\
\text { Jouvet, } \\
\text { D. } \\
\text { Langlois, } \\
\text { and K. } \\
\text { Smaili }\end{array}$} & \multirow[t]{2}{*}{$\begin{array}{l}\text { An enhanced } \\
\text { automatic } \\
\text { speech } \\
\text { recognition } \\
\text { system for } \\
\text { Arabic }\end{array}$} & \multirow[t]{2}{*}{$\begin{array}{l}\text { DNN-HMM, } \\
\text { GMM-HMM }\end{array}$} & \multirow[t]{2}{*}{$\begin{array}{l}\text { Kaldi toolkit, } \\
\text { Auto- } \\
\text { correction of } \\
\text { Hamoza }\end{array}$} & & & & \\
\hline & & & & \multirow{2}{*}{$\begin{array}{l}{[29]} \\
\text { A. Anisa, } \\
\text { A. K. } \\
\text { Jaya, and } \\
\text { S. } \\
\text { Sunarti }\end{array}$} & \multirow{2}{*}{$\begin{array}{l}\text { Analisis } \\
\text { Hidden } \\
\text { Markov } \\
\text { Model untuk } \\
\text { Segmentasi } \\
\text { Barisan DNA }\end{array}$} & \multirow[t]{2}{*}{$\begin{array}{l}\text { HMM, } \\
\text { metode } \\
\text { Cluster } \\
\text { Analysis }\end{array}$} & \multirow[t]{2}{*}{$\begin{array}{l}\text { GenBank, } \\
\text { Matlab }\end{array}$} \\
\hline $\begin{array}{l}\text { [23] } \\
\text { A. H. } \\
\text { Koosasi, }\end{array}$ & $\begin{array}{l}\text { Deteksi } \\
\text { Fraud } \\
\text { Menggunakan }\end{array}$ & $\begin{array}{l}\text { HMM, } \\
\text { Algoritma } \\
\text { Baum-Welch, }\end{array}$ & $\begin{array}{l}\text { Alat ukur } \\
\text { kualitas } \\
\text { statistik seperti }\end{array}$ & & & & \\
\hline $\begin{array}{l}\text { R. Sarno, } \\
\text { and A. } \\
\text { Munif }\end{array}$ & $\begin{array}{l}\text { Metode } \\
\text { Model } \\
\text { Markov } \\
\text { Tersembunyi } \\
\text { pada Proses } \\
\text { Bisnis }\end{array}$ & $\begin{array}{l}\text { Algoritma } \\
\text { Viterbi }\end{array}$ & $\begin{array}{l}\text { akurasi, } \\
\text { presisi, } \\
\text { sensitivitas } \\
\text { (True Positive } \\
\text { Rate atau } \\
\text { TPR) dan } \\
\text { spesifisitas } \\
\text { (True Negative } \\
\text { Rate atau } \\
\text { TNR) }\end{array}$ & $\begin{array}{l}{[30]} \\
\text { Q. Nada, } \\
\text { C. } \\
\text { Ridhuand } \\
\text { i, P. } \\
\text { Santoso, } \\
\text { and D. } \\
\text { Apriyant } \\
\text { o }\end{array}$ & $\begin{array}{l}\text { Speech } \\
\text { Recognition } \\
\text { dengan } \\
\text { Hidden } \\
\text { Markov } \\
\text { Model untuk } \\
\text { Pengenalan } \\
\text { dan Pelafalan } \\
\text { Huruf } \\
\text { Hijaiyah }\end{array}$ & $\begin{array}{l}\text { HMM, } \\
\text { metode Fast } \\
\text { Fourier } \\
\text { Transform } \\
\text { (FFT) }\end{array}$ & $\begin{array}{l}\text { Euclidean } \\
\text { distance, } \\
\text { akurasi }\end{array}$ \\
\hline $\begin{array}{l}{[24]} \\
\text { N. } \\
\text { Nguyen }\end{array}$ & $\begin{array}{l}\text { An Analysis } \\
\text { and } \\
\text { Implementati } \\
\text { on of the } \\
\text { Hidden } \\
\text { Markov } \\
\text { Model to }\end{array}$ & HMM & $\begin{array}{l}\text { Akaike } \\
\text { information } \\
\text { criterion } \\
\text { (AIC), } \\
\text { Bayesian } \\
\text { information } \\
\text { criterion (BIC) }\end{array}$ & $\begin{array}{l}\text { [31] } \\
\text { E. F. } \\
\text { Yuwitani } \\
\text { ng, B. } \\
\text { Hidayat, } \\
\text { and N. } \\
\text { Andini }\end{array}$ & $\begin{array}{l}\text { Implementasi } \\
\text { Metode } \\
\text { Hidden } \\
\text { Markov } \\
\text { Model Untuk } \\
\text { Deteksi } \\
\text { Tulisan }\end{array}$ & $\begin{array}{l}\text { HMM, } \\
\text { metode } \\
\text { Modified } \\
\text { Direction } \\
\text { Feature } \\
\text { (MDF) }\end{array}$ & $\begin{array}{l}\text { Database } \\
\text { tulisan tangan } \\
\text { dalam bentuk } \\
\text { format JPG, } \\
\text { pengukuran } \\
\text { character } \\
\text { error rate }\end{array}$ \\
\hline
\end{tabular}




\begin{tabular}{|c|c|c|c|}
\hline & Tangan & & (CER) \\
\hline $\begin{array}{l}\text { Peneliti } \\
\text { (a) }\end{array}$ & $\begin{array}{c}\text { Judul } \\
\text { (b) }\end{array}$ & $\begin{array}{l}\text { Model } \\
\text { (c) }\end{array}$ & $\begin{array}{l}\text { Properti } \\
\text { (d) }\end{array}$ \\
\hline $\begin{array}{l}{[32]} \\
\text { Y. } \\
\text { Rosmans } \\
\text { yah and } \\
\text { R. R. A. } \\
\text { Wicaksa } \\
\text { na }\end{array}$ & $\begin{array}{l}\text { Perancangan } \\
\text { Aplikasi } \\
\text { Multimedia } \\
\text { Dengan } \\
\text { Menggunakan } \\
\text { Hidden } \\
\text { Markov } \\
\text { Model Untuk } \\
\text { Menentukan } \\
\text { Gaya Belajar }\end{array}$ & $\begin{array}{l}\text { HMM, } \\
\text { metode } \\
\text { clustering, } \\
\text { waterfall }\end{array}$ & $\begin{array}{l}3 D \text { VLE } \\
\text { (Moodle, } \\
\text { SLOODLE, } \\
\text { dan OpenSim), } \\
\text { pengujian } \\
\text { whitebox, } \\
\text { algoritma } k \text { - } \\
\text { means }\end{array}$ \\
\hline $\begin{array}{l}{[33]} \\
\text { B. H. } \\
\text { Prasetio, } \\
\text { W. } \\
\text { Kurniaw } \\
\text { an, and } \\
\text { M. H. H. } \\
\text { Ichsan }\end{array}$ & $\begin{array}{l}\text { Pengenalan } \\
\text { Emosi } \\
\text { Berdasarkan } \\
\text { Suara } \\
\text { Menggunakan } \\
\text { HMM }\end{array}$ & HMM & $\begin{array}{l}\text { Database } \\
\text { suara dari } \\
\text { rekaman film, } \\
\text { alat ukur } \\
\text { berupa akurasi } \\
\text { dan waktu } \\
\text { eksekusi }\end{array}$ \\
\hline $\begin{array}{l}{[34]} \\
\text { B. Cong } \\
\text { Giao, T. } \\
\text { Hoai An, } \\
\text { N. Thi } \\
\text { Hong } \\
\text { Anh, and } \\
\text { H. Nhut } \\
\text { Minh }\end{array}$ & $\begin{array}{l}\text { Hidden } \\
\text { Markov } \\
\text { Model for } \\
\text { Recognition } \\
\text { of Skeletal } \\
\text { data-based } \\
\text { hand } \\
\text { movement } \\
\text { gestures } \\
\end{array}$ & HMM & $\begin{array}{l}\text { Algoritma } \\
\text { Principle } \\
\text { Component } \\
\text { Analysis } \\
\text { (PCA), data } \\
\text { skeletal, } \\
\text { kamera }\end{array}$ \\
\hline $\begin{array}{l}\text { [35] } \\
\text { S. M. } \\
\text { Mon and } \\
\text { H. M. } \\
\text { Tun }\end{array}$ & $\begin{array}{l}\text { Speech-To- } \\
\text { Text } \\
\text { Conversion } \\
\text { (STT) System } \\
\text { Using Hidden } \\
\text { Markov } \\
\text { Model } \\
(\text { HMM) }\end{array}$ & HMM & $\begin{array}{l}\text { Mel } \\
\text { Frequency } \\
\text { Cepstral } \\
\text { Coefficients } \\
\text { (MFCC), } \\
\text { Matlab }\end{array}$ \\
\hline $\begin{array}{l}{[36]} \\
\text { D. } \\
\text { Abdullah } \\
\text { and C. I. } \\
\text { Erliana }\end{array}$ & $\begin{array}{l}\text { Aplikasi } \\
\text { Pengenalan } \\
\text { Ucapan Huruf } \\
\text { Jepang } \\
\text { Menggunakan } \\
\text { Hidden } \\
\text { Markov } \\
\text { Model } \\
\text { (HMM) }\end{array}$ & HMM & $\begin{array}{l}\text { Database } \\
\text { huruf } \\
\text { konsonan } \\
\text { Hiragana, } \\
\text { metode } \\
\text { statistik mean } \\
\text { dan } \\
\text { transformasi } \\
\text { Mellin }\end{array}$ \\
\hline $\begin{array}{l}\text { [37] } \\
\text { A. } \\
\text { Jamaludi } \\
\text { n, A. F. } \\
\text { Huda, } \\
\text { and R. } \\
\text { Sahyanda } \\
\text { ri }\end{array}$ & $\begin{array}{l}\text { Pengenalan } \\
\text { Lafal Hukum } \\
\text { Nun Mati } \\
\text { Menggunakan } \\
\text { Hidden } \\
\text { Markov } \\
\text { Model }\end{array}$ & HMM & $\begin{array}{l}\text { Mel } \\
\text { Frequency } \\
\text { Cepstral } \\
\text { Coefficients } \\
\text { (MFCC), } \\
\text { Vector } \\
\text { Quantization }\end{array}$ \\
\hline
\end{tabular}

TABEL II

HASIL PENELITIAN DAN ANALISIS BAGIAN 2

\begin{tabular}{|l|l|l|}
\hline \multicolumn{1}{|c|}{$\begin{array}{c}\text { Peneliti } \\
\text { (a) }\end{array}$} & \multicolumn{1}{c|}{$\begin{array}{c}\text { Hasil } \\
\text { (e) }\end{array}$} & \multicolumn{1}{c|}{$\begin{array}{c}\text { Catatan } \\
\text { (f) }\end{array}$} \\
\hline [2] & $\begin{array}{l}\text { Mengukur } \\
\text { kesamaan antar } \\
\text { dua sekuensial }\end{array}$ & $\begin{array}{l}\text { Kompleksitas } \\
\text { algoritma DTW } \\
\text { tidak memuaskan }\end{array}$ \\
\hline
\end{tabular}

\begin{tabular}{|c|c|c|}
\hline & $\begin{array}{l}\text { pada waktu dan } \\
\text { kecepatan yang } \\
\text { berbeda }\end{array}$ & $\begin{array}{l}\text { untuk kamus atau } \\
\text { kosa kata yang lebih } \\
\text { banyak dan luas dan } \\
\text { sulit mengevaluasi } \\
\text { dua elemen dari dua } \\
\text { sekuen yang } \\
\text { berbeda waktu dan } \\
\text { kecepatannya }\end{array}$ \\
\hline $\begin{array}{l}\text { Peneliti } \\
\text { (a) }\end{array}$ & $\begin{array}{c}\text { Hasil } \\
\text { (e) }\end{array}$ & $\begin{array}{c}\text { Catatan } \\
\text { (f) }\end{array}$ \\
\hline $\begin{array}{l}\text { [3] } \\
\text { C. P. Dalmiya, } \\
\text { V. S. Dharun, } \\
\text { and K. P. } \\
\text { Rajesh }\end{array}$ & $\begin{array}{l}\text { Aplikasi } \\
\text { Pengenalan } \\
\text { bahasa Tamil } \\
\text { melalui MFCC- } \\
\text { DTW via aplikasi } \\
\text { mobile. LPC- } \\
\text { HMM digunakan } \\
\text { sebagai } \\
\text { pembanding hasil } \\
\text { pengujian dan } \\
\text { MFCC-DTW } \\
\text { lebih tepat dalam } \\
\text { mengenali bahasa } \\
\text { Tamil melalui } \\
\text { aplikasi mobile }\end{array}$ & $\begin{array}{l}\text { Tulisan ini tidak } \\
\text { menginformasikan } \\
\text { sumber bahasa } \\
\text { Tamil yang } \\
\text { diujikan. Penelitian } \\
\text { satu arah, yakni } \\
\text { pengenalan teks ke } \\
\text { ucapan via aplikasi } \\
\text { mobile. Penelitian } \\
\text { masih dapat } \\
\text { dikembangkan dari } \\
\text { ucapan ke teks. }\end{array}$ \\
\hline $\begin{array}{l}\text { [4] } \\
\text { G. Muhammad, } \\
\text { Y. A. Alotaibi, } \\
\text { and M. N. Huda }\end{array}$ & $\begin{array}{l}\text { Mengenali bahasa } \\
\text { Bangla dan } \\
\text { jumlah digit setiap } \\
\text { kata yang } \\
\text { diucapkan }\end{array}$ & $\begin{array}{l}\text { Belum dapat } \\
\text { mendeteksi kata } \\
\text { atau bahasa Bangla } \\
\text { secara tepat karena } \\
\text { adanya perbedaan } \\
\text { pengucapan pria } \\
\text { dan wanita. } \\
\text { menyebabkan } \\
\text { panjang digit kata } \\
\text { yang dibaca sistem } \\
\text { jadi berbeda. }\end{array}$ \\
\hline $\begin{array}{l}{[6]} \\
\text { A. Trivedi, N. } \\
\text { Pant, P. Shah, } \\
\text { S. Sonik, and S. } \\
\text { Agrawal }\end{array}$ & $\begin{array}{l}\text { Mengubah text-to- } \\
\text { speech (TTS) dan } \\
\text { speech-to-text } \\
\text { (STT) via phone- } \\
\text { calls dan } \\
\text { informasi tentang } \\
\text { tipe speech, } \\
\text { speech } \\
\text { recognition, } \\
\text { speech to text } \\
\text { conversion, text to } \\
\text { speech } \\
\text { conversion and } \\
\text { speech translation }\end{array}$ & $\begin{array}{l}\text { Dibutuhkan } \\
\text { referensi yang lebih } \\
\text { banyak untuk } \\
\text { melihat kinerja TTS } \\
\text { dan STT pada } \\
\text { media selain phone- } \\
\text { cells }\end{array}$ \\
\hline $\begin{array}{l}{[19]} \\
\text { J. M. T. S., D. } \\
\text { Puspitaningrum, } \\
\text { and B. Susilo }\end{array}$ & $\begin{array}{l}\text { Aplikasi } \\
\text { Pengenalan suara } \\
\text { untuk permainan } \\
\text { teka-teki silang } \\
\text { pada desktop }\end{array}$ & $\begin{array}{l}\text { Tingkat noise masih } \\
\text { tinggi. Penelitian } \\
\text { dapat } \\
\text { dikembangkan pada } \\
\text { aplikasi mobile }\end{array}$ \\
\hline $\begin{array}{l}{[22]} \\
\text { M. A. Menacer, } \\
\text { O. Mella, D. } \\
\text { Fohr, D. Jouvet, } \\
\text { D. Langlois, } \\
\text { and K. Smaili }\end{array}$ & $\begin{array}{l}\text { ASR untuk } \\
\text { pengenalan bahasa } \\
\text { Arab dengan } \\
\text { Modern Standard } \\
\text { Arabic. Sistem } \\
\text { diukur dengan } \\
\text { DNN-HMM } \\
\text { model, a 4-grams } \\
\text { pruned LM dan } a\end{array}$ & $\begin{array}{l}\text { Kesulitan dalam } \\
\text { melakukan auto- } \\
\text { correct pada kata } \\
\text { atau bahasa karena } \\
\text { satu kata dalam } \\
\text { bahasa Arab } \\
\text { memiliki satu arti } \\
\text { dan dapat berbeda } \\
\text { arti apabila bertemu }\end{array}$ \\
\hline
\end{tabular}




\begin{tabular}{|c|c|c|}
\hline & $\begin{array}{l}\text { lexicon } \\
\text { of } 95 \mathrm{k} \text { words }\end{array}$ & $\begin{array}{l}\text { dengan huruf lain. } \\
\text { Auto-correct juga } \\
\text { sulit dilakukan } \\
\text { karena kesalahan } \\
\text { tulisan dan ejaan } \\
\text { semantik }\end{array}$ \\
\hline $\begin{array}{c}\text { Peneliti } \\
\text { (a) }\end{array}$ & $\begin{array}{c}\text { Hasil } \\
\text { (e) }\end{array}$ & $\begin{array}{c}\text { Catatan } \\
\text { (f) }\end{array}$ \\
\hline $\begin{array}{l}\text { [23] } \\
\text { A. H. Koosasi, } \\
\text { R. Sarno, and } \\
\text { A. Munif }\end{array}$ & $\begin{array}{l}\text { Menemukan } \\
\text { berbagai fraud } \\
\text { dalam proses } \\
\text { bisnis dan } \\
\text { mengklasifikasi } \\
\text { berdasarkan } \\
\text { penyimpangan } \\
\text { yang terjadi. }\end{array}$ & $\begin{array}{l}\text { Sejumlah fraud } \\
\text { yang ditemukan } \\
\text { menimbulkan } \\
\text { keraguan. Perlu } \\
\text { melakukan optimasi } \\
\text { sensitivitas maupun } \\
\text { spesifisitas deteksi, } \\
\text { dengan variasi } \\
\text { atribut yang lebih } \\
\text { beragam, dan } \\
\text { pemberian } \\
\text { informasi masing- } \\
\text { masing atribut } \\
\text { secara jelas, } \\
\text { menurut kelas } \\
\text { riilnya }\end{array}$ \\
\hline $\begin{array}{l}{[24]} \\
\text { N. Nguyen }\end{array}$ & $\begin{array}{l}\text { Membuat prediksi } \\
\text { harga untuk } \\
\text { persediaan tiga } \\
\text { trading media, } \\
\text { yakni google, } \\
\text { apple dan } \\
\text { facebook } \\
\text { berdasarkan data } \\
\text { yang telah lalu }\end{array}$ & $\begin{array}{l}\text { Penelitian ini dapat } \\
\text { memperjelas dan } \\
\text { menambah kriteria } \\
\text { yang menjadi dasar } \\
\text { prediksi harga. } \\
\text { Penelitian dapat } \\
\text { dikembangkan } \\
\text { menggunakan } \\
\text { HMM-DTW karena } \\
\text { data uji yang } \\
\text { berbentuk time } \\
\text { series. }\end{array}$ \\
\hline $\begin{array}{l}\text { [25] } \\
\text { J. Lemos, S. } \\
\text { Patil, S. Save, } \\
\text { and H. Pise }\end{array}$ & $\begin{array}{l}\text { Mendeteksi } \\
\text { adanya penipuan } \\
\text { pada transaksi } \\
\text { kartu kredit } \\
\text { melalui beberapa } \\
\text { kriteria informasi } \\
\text { tentang kartu } \\
\text { kredit dengan } \\
\text { membandingkan } \\
\text { HMM dan Nä̈ve } \\
\text { Bayes }\end{array}$ & $\begin{array}{l}\text { Penelitian ini } \\
\text { menggunakan } \\
\text { simulasi data } \\
\text { pemegang kartu } \\
\text { kredit, bukan data } \\
\text { yang sebenarnya } \\
\text { sehingga hasil } \\
\text { deteksi tidak dapat } \\
\text { dikomparasi } \\
\text { kebenarannya } \\
\text { dengan data } \\
\text { sebenarnya. Hasil } \\
\text { penelitian lebih } \\
\text { kepada } \\
\text { memperlihatkan } \\
\text { kinerja dua metode } \\
\text { yakni HMM dan } \\
\text { Nä̈ve Bayes. }\end{array}$ \\
\hline $\begin{array}{l}{[26]} \\
\text { S. Bhende, K. } \\
\text { Thakur, J. } \\
\text { Teseng, M. L. } \\
\text { Ali, and N. } \\
\text { Wang }\end{array}$ & $\begin{array}{l}\text { Menghasilkan } \\
\text { sebuah model } \\
\text { untuk mendeteksi } \\
\text { tulisan tangan } \\
\text { secara berurut } \\
\text { yang dimulai dari } \\
\text { awal penulisan }\end{array}$ & $\begin{array}{l}\text { Hasil pengujian } \\
\text { menunjukkan } \\
\text { bahwa metode yang } \\
\text { digunakan bekerja } \\
\text { sangat lambat } \\
\text { dalam mengenali } \\
\text { tulisan tangan dan } \\
\text { masih terdapat hasil } \\
\text { perhitungan yang } \\
\text { tidak succulent. }\end{array}$ \\
\hline
\end{tabular}

\begin{tabular}{|c|c|c|}
\hline & & $\begin{array}{l}\text { Penelitian dapat } \\
\text { dikembangkan } \\
\text { dengan mengurangi } \\
\text { dimensi dan fitur } \\
\text { vector serta } \\
\text { memberikan batas } \\
\text { maksimum karakter } \\
\text { yang dapat diujikan. }\end{array}$ \\
\hline $\begin{array}{l}\text { Peneliti } \\
\text { (a) }\end{array}$ & $\begin{array}{c}\text { Hasil } \\
\text { (e) }\end{array}$ & $\begin{array}{c}\text { Catatan } \\
\text { (f) }\end{array}$ \\
\hline $\begin{array}{l}\text { [27] } \\
\text { R. Alghamdi }\end{array}$ & $\begin{array}{l}\text { Penelitian ini } \\
\text { menghasilkan } \\
\text { tinjauan tentang } \\
\text { penerapan } \\
\text { modifikasi HMM } \\
\text { menggunakan set } \\
\text { data yang real- } \\
\text { time, contoh data } \\
\text { pada drilling } \\
\text { system berbeda }\end{array}$ & $\begin{array}{l}\text { Akurasi hasil } \\
\text { penelitian perlu } \\
\text { ditingkatkan karena } \\
\text { penggunaan } \\
\text { sejumlah properti } \\
\text { dapat } \\
\text { mempengaruhi hasil } \\
\text { perhitungan HMM }\end{array}$ \\
\hline $\begin{array}{l}\text { [28] } \\
\text { D. Abdullah } \\
\text { and R. } \\
\text { Ramadhan }\end{array}$ & $\begin{array}{l}\text { Penelitian ini } \\
\text { menghasilkan } \\
\text { sebuah aplikasi } \\
\text { yang } \\
\text { mengeksekusi } \\
\text { fungsi aplikasi } \\
\text { winamp } \\
\text { menggunakan } \\
\text { perintah suara. } \\
\text { Normalisasi } \\
\text { menggunakan } \\
\text { metode Linier } \\
\text { Predictive Coding } \\
\text { (LPC) dan } \\
\text { probabilitas suara } \\
\text { dihitung dengan } \\
\text { HMM }\end{array}$ & $\begin{array}{l}\text { Hasil pengujian } \\
\text { menunjukkan } \\
\text { bahwa HMM dapat } \\
\text { mengukur sinyal } \\
\text { suara untuk } \\
\text { menjalankan } \\
\text { aplikasi winamp. } \\
\text { Aplikasi ini masih } \\
\text { dapat } \\
\text { dikembangkan pada } \\
\text { perintah suara yang } \\
\text { lebih banyak. }\end{array}$ \\
\hline $\begin{array}{l}{[29]} \\
\text { A. Anisa, A. K. } \\
\text { Jaya, and S. } \\
\text { Sunarti }\end{array}$ & $\begin{array}{l}\text { Menghasilkan } \\
\text { analisis } \\
\text { segmentasi DNA } \\
\text { manusia untuk } \\
\text { untuk } \\
\text { mengidentifikasi } \\
\text { dan } \\
\text { memprediksikan } \\
\text { pola kemunculan } \\
\text { basa A, C, T, dan } \\
\text { G dari sebuah } \\
\text { DNA }\end{array}$ & $\begin{array}{l}\text { Penelitian ini dapat } \\
\text { membentuk } \\
\text { segmentasi DNA } \\
\text { menurut basa A, C, } \\
\mathrm{T}, \mathrm{G} \text { namun nilai } \\
\text { transisi yang } \\
\text { dihasilkan tidak } \\
\text { besar. Hal ini dapat } \\
\text { disebabkan oleh } \\
\text { peluang dan } \\
\text { perulangan yang } \\
\text { dilakukan. Peluang } \\
\text { ini memungkinkan } \\
\text { munculnya nilai } \\
\text { transisi yang besar } \\
\text { maupun kecil. }\end{array}$ \\
\hline $\begin{array}{l}{[30]} \\
\text { Q. Nada, C. } \\
\text { Ridhuandi, P. } \\
\text { Santoso, and D. } \\
\text { Apriyanto }\end{array}$ & $\begin{array}{l}\text { Sebuah antar } \\
\text { muka mesin } \\
\text { berbasis suara } \\
\text { untuk pelafalan } \\
\text { huruf hijaiyah }\end{array}$ & $\begin{array}{l}\text { Pengujian untuk } \\
\text { huruf yang berbeda } \\
\text { baru mencapai } 50 \% \\
\text { lebih. Hal ini masih } \\
\text { dapat ditingkatkan } \\
\text { dengan } \\
\text { menggunakan } \\
\text { rumus jarak lainnya }\end{array}$ \\
\hline $\begin{array}{l}\text { [31] } \\
\text { E. F. } \\
\text { Yuwitaning, B. }\end{array}$ & $\begin{array}{l}\text { Sebuah aplikasi } \\
\text { pendeteksi tulisan } \\
\text { tangan }\end{array}$ & $\begin{array}{l}\text { Penelitian ini } \\
\text { sebaiknya } \\
\text { menampilkan }\end{array}$ \\
\hline
\end{tabular}




\begin{tabular}{|c|c|c|}
\hline $\begin{array}{l}\text { Hidayat, and N. } \\
\text { Andini }\end{array}$ & & $\begin{array}{l}\text { beberapa contoh } \\
\text { tulisan tangan } \\
\text { sebagai data uji. } \\
\text { Tulisan yang } \\
\text { tumpang tindih } \\
\text { dapat } \\
\text { mempengaruhi nilai } \\
\text { CER }\end{array}$ \\
\hline $\begin{array}{l}\text { Peneliti } \\
\text { (a) }\end{array}$ & $\begin{array}{c}\text { Hasil } \\
\text { (e) }\end{array}$ & $\begin{array}{l}\text { Catatan } \\
\text { (f) }\end{array}$ \\
\hline $\begin{array}{l}{[32]} \\
\text { Y. Rosmansyah } \\
\text { and R. R. A. } \\
\text { Wicaksana }\end{array}$ & $\begin{array}{l}\text { Sebuah sistem } \\
\text { penentuan gaya } \\
\text { belajar siswa } \\
\text { berdasarkan } 3 \\
\text { cluster, yaitu } \\
\text { cluster } \\
\text { Visual, Auditori, } \\
\text { dan Kinestetik }\end{array}$ & $\begin{array}{l}\text { Sistem ini } \\
\text { menghasilkan nilai } \\
\text { deteksi yang belum } \\
\text { memuaskan, yakni } \\
\text { baru mencapai } 60 \% \\
\text { lebih. Klasifikasi } \\
\text { gaya belajar masih } \\
\text { memungkinkan } \\
\text { untuk dilakukan } \\
\text { dengan tepat } \\
\text { dengan } \\
\text { memanfaatkan web } \\
\text { service. }\end{array}$ \\
\hline $\begin{array}{l}\text { [33] } \\
\text { B. H. Prasetio, } \\
\text { W. Kurniawan, } \\
\text { and M. H. H. } \\
\text { Ichsan }\end{array}$ & $\begin{array}{l}\text { Menghasilkan } \\
\text { sistem yang dapat } \\
\text { mendeteksi tiga } \\
\text { macam emosi, } \\
\text { yakni marah, } \\
\text { bahagia dan netral }\end{array}$ & $\begin{array}{l}\text { Akurasi deteksi } \\
\text { emosi sudah } \\
\text { mencapai } 80 \% \\
\text { lebih. Untuk emosi } \\
\text { netral, masih sulit } \\
\text { diteksi. Ketepatan } \\
\text { prediksi sangat } \\
\text { ditentukan oleh } \\
\text { kualitas suara yang } \\
\text { menjadi input } \\
\text { sistem ini. Suara } \\
\text { yang berasal dari } \\
\text { film memiliki noise } \\
\text { yang sangat tinggi }\end{array}$ \\
\hline $\begin{array}{l}{[34]} \\
\text { B. Cong Giao, } \\
\text { T. Hoai An, N. } \\
\text { Thi Hong Anh, } \\
\text { and H. Nhut } \\
\text { Minh }\end{array}$ & $\begin{array}{l}\text { Sebuah aplikasi } \\
\text { yang dapat } \\
\text { mendeteksi } \\
\text { gerakan tangan } \\
\text { manusia secara } \\
\text { otomatis dalam } \\
\text { bentuk lima } \\
\text { gerakan, yakni } \\
\text { putaran kanan ke } \\
\text { kiri, atas ke } \\
\text { bawah, berputar, } \\
\text { gerakan } 4 \text { arah } \\
\text { dan gerakan } 3 \\
\text { arah } \\
\end{array}$ & $\begin{array}{l}\text { Penelitian ini } \\
\text { menghasilkan } \\
\text { akurasi yang sangat } \\
\text { tinggi yakni lebih } \\
\text { dari } 90 \% \text { untuk } \\
\text { semua gerakan. }\end{array}$ \\
\hline $\begin{array}{l}\text { [35] } \\
\text { S. M. Mon and } \\
\text { H. M. Tun }\end{array}$ & $\begin{array}{l}\text { Menghasilkan } \\
\text { sebuah aplikasi } \\
\text { yang mengubah } \\
\text { sinyal suara } \\
\text { menjadi teks bagi } \\
\text { anak tunarungu } \\
\text { untuk kebutuhan } \\
\text { bidang pendidikan }\end{array}$ & $\begin{array}{l}\text { Aplikasi ini } \\
\text { menghasilkan } \\
\text { tingkat akurasi yang } \\
\text { sangat tinggi, } \\
\text { namun sebaiknya } \\
\text { disertai dengan } \\
\text { pengujian yang } \\
\text { menggunakan data } \\
\text { suara dan tampilan } \\
\text { hasil dalam bentuk } \\
\text { teks }\end{array}$ \\
\hline $\begin{array}{l}\text { [36] } \\
\text { D. Abdullah }\end{array}$ & $\begin{array}{l}\text { Penelitian ini } \\
\text { menghasilkan }\end{array}$ & $\begin{array}{l}\text { Pola ucapan yang } \\
\text { diujikan cukup }\end{array}$ \\
\hline
\end{tabular}

\begin{tabular}{|c|c|c|}
\hline and C. I. Erliana & $\begin{array}{l}\text { sebuah aplikasi } \\
\text { yang dapat } \\
\text { mengenal ucapan } \\
\text { huruf konsonan } \\
\text { Hiragana melalui } \\
\text { pola ucapan yang } \\
\text { diucapkan oleh } 10 \\
\text { orang }\end{array}$ & $\begin{array}{l}\text { jelas. Penelitian ini } \\
\text { dapat } \\
\text { dikembangkan } \\
\text { dengan menguji } \\
\text { pola ucapan yang } \\
\text { lebih banyak lagi } \\
\text { untuk mendapatkan } \\
\text { akurasi kinerja } \\
\text { sistem. }\end{array}$ \\
\hline $\begin{array}{l}\text { Peneliti } \\
\text { (a) }\end{array}$ & $\begin{array}{l}\text { Hasil } \\
\text { (e) }\end{array}$ & $\begin{array}{l}\text { Catatan } \\
\text { (f) }\end{array}$ \\
\hline $\begin{array}{l}\text { [37] } \\
\text { A. Jamaludin, } \\
\text { A. F. Huda, and } \\
\text { R. Sahyandari }\end{array}$ & $\begin{array}{l}\text { Mendeteksi lafal } \\
\text { hukum nun mati } \\
\text { dalam pembacaan } \\
\text { ayat Al-Qur'an } \\
\text { melalui lafal suara } \\
\text { dari beberapa } \\
\text { orang }\end{array}$ & $\begin{array}{l}\text { Sistem ini tidak } \\
\text { berhasil dalam } \\
\text { mendeteksi lafal } \\
\text { huruf nun mati } \\
\text { dengan akurasi } \\
\text { hanya sekitar 50\%. } \\
\text { Hal ini dapat } \\
\text { disebabkan oleh } \\
\text { pelafalan huruf nun } \\
\text { mati yang belum } \\
\text { sesuai dengan } \\
\text { hukum tersebut, } \\
\text { seperti panjang dan } \\
\text { pendek saat } \\
\text { pembacaan dan } \\
\text { huruf yang yang } \\
\text { menyambut nun } \\
\text { mati. Sistem ini } \\
\text { masih } \\
\text { memungkinkan } \\
\text { untuk diujikan } \\
\text { kembali dengan } \\
\text { menggunakan } \\
\text { database yang } \\
\text { benar }\end{array}$ \\
\hline
\end{tabular}

Tabel 1 dan 2 memperlihatkan hasil sebagian penelitian menggunakan HMM yang dijadikan referensi dalam tulisan ini. Berdasarkan analisis terhadap 21 penelitian yang dipilih, peneliti menilai bahwa HMM dapat diklasifikasikan ke dalam tiga bidang penerapan, seperti terdapat pada Tabel 3.

TABEL III

BIDANG PENERAPAN HMM

\begin{tabular}{|l|l|}
\hline \multicolumn{1}{|c|}{ Bidang } & \multicolumn{1}{c|}{ Penelitian (nomor) } \\
\hline Pendidikan & $2,3,4,22,30,32,36,37$ \\
\hline Ekonomi & 23,25 \\
\hline Bisnis dan Industri & $6,19,24,26,27,28,29$, \\
& $31,33,34,35$ \\
\hline
\end{tabular}

Penerapan HMM di bidang pendidikan lebih banyak mengarah pada pengenalan bahasa. HMM pada ekonomi digunakan untuk mendeteksi kecurangan perbankan, sedangkan bidang industri dan bisnis, HMM lebih ditujukan kepada aplikasi yang memiliki nilai komersil.

Untuk melihat tingkat keberhasilan eksekusi HMM, terdapat pada Tabel 4. 
TABEL IV

KLASIFIKASI HMM

\begin{tabular}{|l|l|l|l|}
\hline \multicolumn{1}{|c|}{ Penerapan } & Jumlah & Berhasil & $\begin{array}{c}\text { Tingkat } \\
\text { Keberhasilan }\end{array}$ \\
\hline Pendidikan & 8 & 4 & $50 \%$ \\
\hline Ekonomi & 2 & 2 & $100 \%$ \\
\hline Bisnis dan Industri & 11 & 9 & $81,82 \%$ \\
\hline Total & 21 & 15 & $71,43 \%$ \\
\hline
\end{tabular}

Berdasarkan Tabel 4, penerapan HMM pada bidang pendidikan serta bisnis dan industri, memiliki peluang yang besar untuk dikembangkan, sedangkan untuk penerapan HMM di bidang ekonomi memiliki tingkat keberhasilan yang sempurna. Secara keseluruhan, keberhasilan HMM dalam mendeteksi atau mengenali data mencapai $71,43 \%$. Capaian tersebut dapat terus ditingkatkan melalui penelitian dalam bentuk prediksi dan klasifikasi. Hal ini juga membuktikan bahwa HMM merupakan bagian dari data mining dan soft computing [38] yang mudah dikembangkan ke semua bidang pekerjaan.

\section{KESIMPULAN}

Hidden Markov Model (HMM) merupakan model speech recognition yang sangat fleksibel. Struktur yang komputasi memungkinkan perubahan nilai yang dapat disesuaikan dengan permasalahan. Kesesuaian faktor pendukung seperti kriteria masalah, ukuran data, jumlah data, jarak data, metode atau algoritma kombinasi, sangat menentukan ketepatan pengenalan data baik berupa suara, teks ataupun gambar oleh HMM. Hasil penelitian menunjukkan bahwa tidak semua kasus dapat diselesaikan dengan sempurna oleh HMM. Namun pengujian dengan HMM dalam tulisan ini memperlihatkan tingkat keberhasilan hingga $71,43 \%$.

Pengukuran statistik sangat mendominasi analisis hasil HMM. Hal ini memungkinkan HMM dikembangkan ke arah kombinasi dengan metode klasifikasi dalam data mining. Klasifikasi memang sudah terbentuk, namun secara fundamental dan konsep, belum menghasilkan sebuah model yang sesuai. Tulisan ini diharapkan dapat memberikan dan menambah informasi tentang kinerja HMM secara luas untuk memudahkan pemahaman dan pengembangan penelitian di masa yang akan datang.

\section{REFERENSI}

[1] C. Vimala, "A Review on Speech Recognition Challenges and Approaches," World Comput. Sci. Inf. Technol. J., vol. 2, no. 1, pp. $1-7,2012$.

[2] A. S. Sunny, "Speech Recognition Menggunakan Algoritma Program Dinamis," Speech Recognition menggunakan Algoritma Program Dinamis, p. 4, 2009.

[3] C. P. Dalmiya, V. S. Dharun, and K. P. Rajesh, "An efficient method for Tamil speech recognition using MFCC and DTW for mobile applications," in 2013 IEEE Conference on Information and Communication Technologies, 2013, no. Ict, pp. 1263-1268, doi: 10.1109/CICT.2013.6558295

[4] G. Muhammad, Y. A. Alotaibi, and M. N. Huda, "Automatic speech recognition for Bangla digits," in ICCIT 2009 - Proceeding of 2009 12th International Conference on Computer and Information Technology, 2009, no. Iccit, pp. 379-383, doi
10.1109/ICCIT.2009.5407267.

[5] P. Bhardwaj and S. Debbarma, "A Study of Methods Involved In Voice Emotion Recognition," Int. J. Adv. Res. Comput. Commun. Eng., vol. 3, no. 2, pp. 5517-5521, 2014.

[6] A. Trivedi, N. Pant, P. Shah, S. Sonik, and S. Agrawal, "Speech to text and text to speech recognition systems-Areview," IOSR J. Comput. Eng., vol. 20, no. 2, pp. 36-43, 2018, doi: 10.9790/06612002013643.

[7] E. I. Yuwono and T. Antonio, "Studi Format Audio dan Teks Untuk Modul Speech to Text,” JISI, vol. 1, no. 1, pp. 1-10, 2015.

[8] X. Yuan et al., "CommanderSong: A Systematic Approach for Practical Adversarial Voice Recognition," in Proceedings of the 27th USENIX Security Symposium, 2018, pp. 1-17.

[9] M. K. Titsias, C. C. Holmes, and C. Yau, "Statistical Inference in Hidden Markov Models Using k-Segment Constraints," J. Am. Stat. Assoc., vol. 111, no. 513, pp. 200-215, 2016, doi: 10.1080/01621459.2014.998762.

[10] F. De Wet, N. Kleynhans, D. Van Compernolle, and R. Sahraeian, "Speech recognition for under-resourced languages: Data sharing in hidden Markov model systems," S. Afr. J. Sci., vol. 113, no. 1-2, pp. 1-9, 2017, doi: 10.17159/sajs.2017/20160038.

[11] N. W. Pratiwi, F. Fauziah, S. Andryana, and A. Gunaryati, "Deteksi Wajah Menggunakan Hidden Markov Model (HMM) Berbasis Matlab," STRING (Satuan Tulisan Ris. dan Inov. Teknol., vol. 3, no. 1, pp. 44-49, 2018, doi: 10.30998/string.v3i1.2538.

[12] A. Y. Vadwala, K. A. Suthar, Y. A. Karmakar, and N. Pandya, "Survey paper on Different Speech Recognition Algorithm: Challenges and Techniques," Int. J. Comput. Appl., vol. 175, no. 1 , pp. 31-36, 2017, doi: 10.5120/ijca2017915472.

[13] Y. Lucas et al., "Multiple perspectives HMM-based feature engineering for credit card fraud detection," in Proceedings of the ACM Symposium on Applied Computing, 2019, vol. April, pp. 1359-1361, doi: 10.1145/3297280.3297586.

[14] A. T. Bon and N. Isah, "Hidden Markov Model and ForwardBackward Algorithm in Crude Oil Price Forecasting," in IOP Conference Series: Materials Science and Engineering, 2016, vol. 160, no. 1, pp. 1-6, doi: 10.1088/1757-899X/160/1/012067.

[15] S. W. Mamonto, Y. A. R. Langi, and A. J. Rindengan, "Penerapan Hidden Markov Model Pada Harga Saham," $J d C$, vol. 5, no. 1, pp 35-41, 2016

[16] K. Audhkhasi, O. Osoba, and B. Kosko, "Noisy hidden Markov models for speech recognition," in Proceedings of the International Joint Conference on Neural Networks, 2013, no. 2, pp. 2738-2743, doi: 10.1109/IJCNN.2013.6707088.

[17] S. Febriani, Harianto, and I. Puspasari, "ANALISIS THRESHOLD MENGGUNAKAN METODE HIDDEN MARKOV MODEL,” $J$ Control Netw. Syst., vol. 6, no. 2, pp. 197-206, 2017.

[18] Z. Ghahramani, "An Introduction to Hidden Markov Models and Bayesian Networks," J. Pattern Recognit. Artif. Intell., vol. 15, no. 1, pp. 9-42, 2001.

[19] J. M. T. S., D. Puspitaningrum, and B. Susilo, "Penerapan Speech Recognition Pada Permainan Teka-Teki Silang Menggunakan Metode Hidden Markov Model (HMM) Berbasis Desktop," $J$. Rekrusif, vol. 4, no. 1, pp. 119-129, 2016.

[20] K. S. Saksamudre, P. P. Shrishrimal, and R. R. Deshmukh, "A Review on Different Approaches for Speech Recognition System," Int. J. Comput. Appl., vol. 115, no. 22, pp. 23-28, 2015, doi: 10.5120/20284-2839.

[21] M. Gales and S. Young, "The application of hidden Markov Models in speech recognition," Found. Trends Signal Process., vol. 1, no. 3, pp. 195-304, 2007, doi: 10.1561/2000000004.

[22] M. A. Menacer, O. Mella, D. Fohr, D. Jouvet, D. Langlois, and K. Smaili, "An enhanced automatic speech recognition system for Arabic," in Proceedings ofThe Third Arabic Natural Language Processing Workshop (WANLP), 2017, pp. 157-165, doi: $10.18653 / \mathrm{v} 1 / \mathrm{w} 17-1319$

[23] A. H. Koosasi, R. Sarno, and A. Munif, "Deteksi Fraud Menggunakan Metode Model Markov Tersembunyi Pada Proses Bisnis," J. Tek. ITS, vol. 6, no. 1, pp. 24-28, 2017, doi 10.12962/j23373539.v6i1.22328.

[24] N. Nguyen, "An Analysis and Implementation of the Hidden Markov Model to Technology Stock Prediction," Risks, vol. 5, no. 62, pp. 1-16, 2017, doi: 10.3390/risks5040062. 
[25] J. Lemos, S. Patil, S. Save, and H. Pise, "Credit card fraud detection using Hidden Markov Model and Naive Bayes," IOSR J. Comput. Eng., vol. 21, no. 2, pp. 72-76, 2019, doi: 10.1109/TDSC.2007.70228.

[26] S. Bhende, K. Thakur, J. Teseng, M. L. Ali, and N. Wang, "Character recognition using hidden markov models," Int. J. Recent Technol. Eng., vol. 7, no. 4S2, pp. 105-110, 2018.

[27] R. Alghamdi, "Hidden Markov Models (HMMs) and Security Applications," Int. J. Adv. Comput. Sci. Appl., vol. 7, no. 2, pp. 3947, 2016, doi: 10.14569/ijacsa.2016.070205.

[28] D. Abdullah and R. Ramadhan, "Implementasi Algoritma Hidden Markov Model Sebagai Pengenalan,” J. Pseudocode, vol. III, no. 1, pp. 15-25, 2016.

[29] A. Anisa, A. K. Jaya, and S. Sunarti, "Analisis Hidden Markoy Model untuk Segmentasi Barisan DNA," J. Mat. Stat. dan Komputasi, vol. 13, no. 1, pp. 55-65, 2016, doi: 10.20956/JMSK.V13I1.3484.

[30] Q. Nada, C. Ridhuandi, P. Santoso, and D. Apriyanto, "Speech Recognition dengan Hidden Markov Model untuk Pengenalan dan Pelafalan Huruf Hijaiyah,” J. Al-Azhar Indones. Seri Sains dan Teknol., vol. 5, no. 1, pp. 19-26, 2019.

[31] E. F. Yuwitaning, B. Hidayat, and N. Andini, "Implementasi Metode Hidden Markov Model untuk Deteksi Tulisan Tangan," $e$ Proceeding Eng., vol. 1, no. 1, pp. 396-402, 2014.

[32] Y. Rosmansyah and R. R. A. Wicaksana, "Perancangan Aplikasi Multimedia Dengan Menggunakan Hidden Markov Model Untuk Menentukan Gaya Belajar," J. Sosioteknologi, vol. 17, no. 2, pp 305-315, 2018, doi: 10.5614/sostek.itbj.2018.17.2.12.

[33] B. H. Prasetio, W. Kurniawan, and M. H. H. Ichsan, "Pengenalan Emosi Berdasarkan Suara Menggunakan Algoritma HMM," $J$ Teknol. Inf. dan Ilmu Komput., vol. 4, no. 3, pp. 168-172, 2017, doi: 10.25126/jtiik.201743339.

[34] B. Cong Giao, T. Hoai An, N. Thi Hong Anh, and H. Nhut Minh, "Hidden Markov Model for recognition of skeletal databased hand movement gestures," EAI Endorsed Trans. Context. Syst. Appl., vol. 4, no. 14, pp. 1-10, 2018, doi: 10.4108/eai.18-6-2018.154819.

[35] S. M. Mon and H. M. Tun, "Speech-To-Text Conversion ( STT ) System Using Hidden Markov Model ( HMM )," Int. J. Sci. Technol. Res., vol. 4, no. 6, pp. 349-352, 2015.

[36] D. Abdullah and C. I. Erliana, "Aplikasi Pengenalan Ucapan Huruf Jepang Menggunakan Hidden Markov Model (HMM)," J. Inf. Syst. Informatics Comput., vol. 1, no. 1, pp. 21-32, 2017, doi: 10.3975/cagsb.2017.02.15

[37] A. Jamaludin, A. F. Huda, and R. Sahyandari, "Pengenalan Lafal Hukum Nun Mati Menggunakan Hidden Markov Model,”Log!K@, vol. 6, no. 1, pp. 1-10, 2016

[38] L. R. Rabiner, "Tutorial on Hmm and Applications.Pdf," in Proceedings of the IEEE, 1989, vol. 77, pp. 257-286, doi: 10.1109/5.18626. 